\title{
PENYERAGAMAN DAN WAJAH BURAM MODERNITAS DI KOTA MAKASSAR PADA MASA ORDE BARU
}

\author{
Ilham \\ Departemen Ilmu Sejarah, Fakultas Ilmu Budaya Universitas Hasanuddin, Makassar - Indonesia \\ Program Doktor Ilmu-ilmu Humaniora, Fakultas Ilmu Budaya, Universitas Gadjah Mada, \\ Yogyakarta-Indonesia
}

Alamat korespondensi: ilhamdaengmakkelo@gmail.com

Diterima/Received: 24 November 2018; Direvisi/Revised: 24 Januari 2019; Disetujui/Accepted: 4 Maret 2019

\begin{abstract}
This article describes modernity in the city of Makassar during the New Order era. The meaning of modernity in this article was a modern idea or thought in the form projects of development (modernization) which the state tries to control. The control of the State is manifested in the form of uniformity and mobilization of development projects by the city government. The main impact that arises from the process is problems of the urban, environment of the urban physical and social life of the population of the city. This study uses the approach of urban history. The data used came from archives, newspapers, magazines, and results of interviews. This study shows that uniformity and mobilization of urban development modernity projects touch the lowest level, especially in the regulation and use of urban space and in the activities of urban residents. At the same time, the control and influence of the private sector increasingly determine the use of space. A predetermined city plan often cannot work because it gets intervention from the interests of the private sector. In this conflict of interests, various "disappointments" arose in an attempt to modernize urban space. In urban areas, problems arise in structuring cities and social life which are vulnerable as an impact of an increasingly widespread modernization project. On the other side, the livelihood sources of some urban residents such as the informal sector are increasingly marginalized and have no support from the city government.
\end{abstract}

Keywords: Modernity; Makassar; Urban Problems; New Order.

\begin{abstract}
Abstrak
Artikel ini menjelaskan tentang modernitas di Kota Makassar pada masa Orde Baru. Arti modernitas dalam artikel ini adalah ide atau gagasan modern dalam bentuk proyek-proyek pembangunan (modernisasi) yang berusaha dikendalikan negara. Kontrol negara diwujudkan dalam bentuk penyeragaman dan mobilisasi proyek-proyek pembangunan oleh pemerintah kota. Dampak utama yang muncul dari proses itu adalah permasalahan perkotaan, yakni lingkungan fisik perkotaan dan kehidupan sosial penduduk kota. Penelitian ini menggunakan pendekatan sejarah kota dan menggunakan data sejarah berupa arsip, surat kabar, majalah, dan hasil wawancara. Kajian ini menunjukkan bahwa penyeragaman dan mobilisasi proyek modernitas pembangunan kota menyentuh tingkat paling bawah, terutama pada pengaturan dan penggunaan ruang kota serta dalam aktivitas penduduk kota. Pada saat bersamaan, penguasaan dan pengaruh pihak swasta semakin menentukan dalam penggunaan ruang. Rencana kota yang telah ditetapkan sering kali tidak bisa berjalan karena mendapat intervensi kepentingan pihak swasta. Dalam sengkarut kepentingan itu, timbul berbagai "kekecewaan" pada usaha modenisasi ruang kota. Di ruang perkotaan timbul permasalahan pada penataan kota dan pada kehidupan sosial yang rentan sebagai imbas dari proyek modernisasi yang semakin meluas. Pada pihak lain, sumber penghidupan sebagian penduduk kota seperti sektor informal semakin tersisih dan tidak mendapat dukungan dari pemerintah kota.
\end{abstract}

Kata Kunci: Modernitas; Kota Makassar; Permasalahan Perkotaan; Orde Baru. 


\section{PENDAHULUAN}

Pembangunan yang dijalankan melalui misi "pembudayaan" masyarakat pada masa Orde Baru menciptakan kebijakan yang mirip terjadi pada masa kolonial, khususnya terhadap pengaturan penduduk dan pembatasan kebebasan. Pemerintah Orde Baru mereposisi arti, makna, cara, dan kebijakan untuk mewujudkan kemajuan yang diinginkan, yakni suatu modernitas yang seragam dan terkontrol. Pembangunan menjadi pembenaran bagi model budaya komando yang lebih mengistimewakan modernisasi daripada mobilisasi (politik) masyarakat. Penekanannya terutama pada modernisasi yang dipimpin negara ketimbang model "organis", dimana partisipasi dan kreativitas warga negara difasilitasi.

Modernitas di perkotaan berjalan di bawah dominasi kekuasaan Orde Baru melalui instrumen birokratisasi hingga ke level paling bawah. Hal itu tampak pada usaha rezim Orde Baru untuk mengatur, baik langsung maupun tidak langsung perilaku warga negara. Mengenai hal ini, Jones (2015: 150) menyatakan bahwa praktik kekuasaan Orde Baru tidak saja keinginan untuk mendapatkan dominasi, tetapi melakukan berbagai upaya dan strategi dalam menciptakan situasi yang diatur, dikendalikan, diadaptasi, dan akhirnya diperintah.

Pada sisi lain, pembangunan ekonomi dan politik di tingkat negara dan kebijakan pemerintah kota di tingkat lokal telah menciptakan "ketersisihan", terutama bagi penduduk yang tidak memiliki akses pada kekuasaan dan sumbersumber ekonomi. Sektor ekonomi informal tumbuh sebagai sabuk pengaman atas ketidakmampuan pemerintah dalam menyediakan lapangan pekerjaan. Namun, sektor ekonomi ini acap kali dipandang negatif, terabaikan dan tergusur dari waktu ke waktu. Menurut Jellinek (1994: 238), setelah 1970-an, rasa ketidakberdayaan penduduk kota meningkat ketika pemerintah melakukan penetrasi lebih jauh ke dalam kehidupan mereka.

Perkembangan kota melalui pembangunan fisik kota secara besar-besaran pada masa Orde Baru melahirkan permasalahan yang semakin kompleks dan sulit terpecahkan. Di Kota Makassar, permasalahan tersebut tampak dengan nyata baik pada lingkungan (fisik) kota maupun pada permasalahan sosial masyarakat. Permasalahan terutama dirasakan oleh penduduk kota yang tidak mampu menghadapi dan meng-ambil keuntungan dari perubahan yang terjadi. Di samping itu, dalam kehidupan ekonomi kota ditandai dengan terpinggirnya profesi tertentu, seperti sektor informal.

Kajian sejarah tentang modernitas di Kota Makassar pada masa Orde Baru hampir belum dilakukan hingga saat ini. Beberapa tulisan sebelumnya lebih tertarik pada tema sejarah sosial, politik, dan ekonomi di Kota Makassar pada periode tertentu (Paeni, dkk., 1985; Poelinggomang, 2002; Asba, 2000; Limbugau dalam Mukhlis, 1989; Luhukay, tth; Mattaliu \& Pallawa, 1997; Sukatanya dkk., 2000). Tulisan Sutherland (1986: 201) mengenai Kota Makassar mengkaji dinamika perkotaan pada masa kolonial. Kajian Pradadimara (2005) menjelaskan 'etnisisasi' Kota Makassar.

Modernitas dalam kajian ini diartikan sebagai segala hal yang terkait dengan unsur-unsur dan sifat-sifat modern baik dalam ide atau gagasan maupun dalam praktiknya (modernisasi). Wujud modernitas dalam rezim Orde Baru terutama dipraktikkan dalam pembangunan. Dalam suasana ini pula, Kota Makassar sudah dirancang menjadi kota budaya sejak awal Orde Baru. Namun ide dan gagasan modern atau proses modernisasi membawa konsekuensi dalam bentuk permasalahan perkotaan. Permasalahan tersebut merupakan anomali yang terus menumpuk dan tampak bagai ironi modernitas.

\section{METODE}

Cakupan tulisan ini meliputi kebijakan pemerintah kota dalam pembangunan melalui mobilisasi masyarakat, wacana kota budaya sebagai impian kota modern, dan ironi modernitas dalam berbagai bentuk permasalahan perkotaan. Dalam mengungkapkan problematika aspek-aspek yang dibahas, maka penelitian ini menggunakan pendekatan sejarah kota dengan melihat ruang Kota Makassar sebagai determinan utama dalam perkembangan kota. Penggunaan metode sejarah didukung dengan penggunaan konsep dan teori dari ilmu-ilmu bantu. Narasi dibangun dengan menggunakan beberapa variasi sumber. Arsip dan 
dokumen tercetak terutama menggunakan Arsip Kotamadya Ujung Pandang (AKUP) yang tersedia di Badan Arsip dan Perpustakaan Daerah Sulawesi Selatan, serta dokumen yang diterbitkan pemerintah kota yang tersimpan di Perpustakaan Kota Makassar. Sumber yang mencatat berita keseharian dalam Kota Makassar diperoleh dari surat kabar lokal maupun dari beberapa majalah, terutama dari surat kabar Pedoman Rakjat. Informasi dari surat kabar selain berguna untuk menggambarkan keseharian warga kota, juga menjadi pembanding sumber arsip dan dokumen dari berbagai sumber.

Melengkapi data-data tercetak dilakukan wawancara dengan warga kota yang memiliki informasi yang dibutuhkan. Hasil wawancara berguna dalam memperoleh informasi dan narasi sejarah mengenai pengalaman warga kota atas pembangunan lingkungan perkotaan, kehidupan masyarakat, dan permasalahan sosial perkotaan. Penggunaan metode pencarian arsip/dokumen tertulis dan melalui wawancara dalam praktiknya akan saling melengkapi. Adapun sumber-sumber sekunder berupa buku dan artikel menjadi pengetahuan dalam menyusun kerangka tulisan ini. Tulisan ini bertujuan untuk menjelaskan pengadopsian unsur-unsur atau sifat-sifat modern pada masa Orde Baru, peran pemerintah kota (negara), dan dampaknya berupa permasalahan perkotaan.

\section{MOBILISASI MASYARAKAT DALAM MODERNISASI KOTA}

Gerak manusia dan masyarakat perkotaan pada masa Orde Baru, ditandai oleh kekuasaan sentralistik, aktivitas yang terorganisasi dan terkontrol, mengedepankan keseragaman, serta pengaruh militer yang kuat. Teruo Sekimoto menyebutkan bahwa pemerintah Orde Baru mempromosikan keseragaman di seluruh negeri dan menggerakkan masyarakat untuk tujuan nasional yaitu stabilitas ngara dan pembangunan (Sekimoto, 2005: 449). Di Makassar, segala citacita dan cara rezim Orde Baru dalam pembangunan perkotaan dimulai oleh Walikota Muhammad Daeng Patompo. Sebagai perwira militer, program kerjanya dijalankan dengan gaya komando berdasar pada kebijakan yang digariskan pemerintah pusat.

Pada awal kepemimpinan Patompo (19651978), dalam upaya pengembangan kota dan peningkatan kualitas kehidupan sosial masyarakat, maka disusun "Pola Dasar Pembangunan Daerah Kotamadya Makassar 1965-1970” atau dikenal juga sebagai program "Pemberantasan 3K (Kemiskinan, Kemelaratan, dan Kebodohan). Salah satu tujuan penyusunan program tersebut adalah untuk memperbaiki mental aparat pemerintahan, khususnya terhadap sikap apatis, lesu, dan bermasa bodoh. Di pihak lain, penduduk kota juga acuh tak acuh terhadap pemerintah, kriminalitas yang terus meningkat, meluasnya bangunan liar, serta kondisi ruang kota yang kotor dan semrawut. Dalam mengatasi kondisi tersebut, maka diterapkan tindakan tegas dengan pemberian hukuman bagi yang melanggar, dan penghargaan bagi yang disiplin (Majalah Kotapradja, No.9-10, Tahun VII-1978: 10). Sebuah tindakan, yang menurut Michael Foucault merupakan usaha mendisiplinkan sebuah tatanan guna mengontrolnya (Foucault, 1995).

Rezim baru ini mempunyai kemampuan dalam membangun persepsi, sehingga dalam waktu cepat bisa menumbuhkan antipati terhadap rezim lama yang selama memerintah menggunakan semboyan revolusi. Suasana tersebut tergambar pada 1967, ketika civitas akademika se-Kota Makassar dan pemuda seSulawesi Selatan membuat pernyataan menyatakan 'perang' dengan rezim Orde Lama (Pedoman Rakjat, 9 Februari 1967).

Langkah terstruktur selanjutnya adalah mengubah cara berfikir yang dianggap warisan masa lalu. Untuk itu, pada awal 1970-an, dibentuk "Komando Mobilisasi Pembangunan". Tujuan dari pembentukan Komando Mobilisasi Pembangunan ini, selain ditujukan untuk aparat pemerintahan, seluruh penduduk kota diharapkan bergerak di bidang masing-masing, juga dianggap dapat menyukseskan pembangunan dan modernisasi (Pedoman Rakjat, 10 Mei 1966:1; 3 Januari 1972: 1). Dengan demikian, diharapkan dapat mengejar ketertinggalan dalam mencapai kemajuan.

Sejak awal, rezim Orde Baru menyadari bahwa untuk mewujudkan masyarakat modern, 
maka hal pertama yang disiapkan adalah infrastruktur perkotaan. Oleh karena itu, pembangunan ditujukan untuk penyediaan sarana dan prasarana kota, kelancaran komunikasi, sarana pendidikan, kesehatan, perumahan, dan fasilitas perkampungan. Pendidikan atau sekolah dianggap sebagai sumber dan alat modernisasi.

Slogan memberantas kebodohan, disikapi dengan membangun gedung sekolah sebanyak mungkin. Untuk mendukung mewujudkan manusia berilmu dan sehat jasmaniah, maka didirikan sarana kesehatan di setiap kecamatan hingga lingkungan ( $A K U P$, Vol.I, Reg.No.1469; Pedoman Rakjat, 26 Januari 1968: 1; 5 September 1968). Berbagai pihak seperti militer, swasta, lembaga donor internasional, bahkan bantuan negara lain dilibatkan dalam usaha ini ( $A K U P$, Vol.I, Reg.No.580). Dengan demikian, penyediaan sarana dan prasarana itu, sekaligus menjadi ruang masuk pemerintah (negara) kota, untuk melakukan intervensi dan kontrol kepada kehidupan masyarakat.

Dalam dekade kedua Orde Baru, terbangun pola komunikasi dan aktivitas sosial penduduk perkotaan dengan gaya baru yang mengedepankan keserasian, mobilisasi, dan keseragaman, khususnya dalam ide dan sikap. Mobilisasi untuk keseragaman di tingkat penduduk banyak diciptakan, seperti aktivitas bersama dalam mengatasi persoalan lingkungan, yang dilakukan dengan "kerja bakti", terutama dalam pembersihan kota, maupun perawatan berbagai fasilitas perkotaan. Kedisiplinan berlalu lintas juga dikampanyekan, baik melalui sosialisasi, organisasi tertib lalu lintas, maupun kegiatan bernuansa seni seperti pemilihan "ratu scooter dan pangeran motor" tahun 1970-an (Pedoman Rakjat, 5 Mei 1966; 9 Mei 1966; 28 Oktober 1967; 1 Mei 1970).

Gagasan modernitas pada masa Orde Baru identik dengan pengaturan sosial. Hal itu tampak pada aturan atau kebijakan pemerintah dalam merespons kebutuhan penduduk. Untuk kelancaran transportasi dalam kota, Perusahaan Daerah (PD) Pengangkutan Udjung Pandang, pada tahun 1967 menetapkan jalur angkutan umum. Di sepanjang jalur tersebut, terdapat beberapa tempat pemberhentian (halte) bis kota. Fasilitas tersebut menjadikan kota-kota di luar Makassar, terhubung dan saling menunjang satu sama lain siang dan malam. Selain angkutan regular di siang hari, dibuka juga trayek bis (cepat) malam. Bagi mereka yang ingin bepergian ke luar kota yang hendak menuju stasiun bis malam diberikan fasilitas gratis menumpang bis kota dengan menunjukkan tiket bis malamnya (Pedoman Rakjat, 25 Februari 1967; 3 Maret 1967).

Kegiatan ekonomi dipusatkan di Pasar Sentral Makassar yang dibangun secara modern dan lengkap. Beberapa pasar ditutup dan digabung ke Pasar Sentral. Pada 1969, aktivitas pedagang pasar diorganisasi dengan pembentukan empat organisasi pasar yakni Koperasi Persatuan Pendjual Keperluan Harian, Jajasan Central Raja Makassar, Pendjual Belik-Belik Terbesar Pasar Sentral, dan Persatuan Pendjual Kain Pasar Sentral Makassar. Organisasi itulah yang berhubungan dengan Pemerintah Kota dan sekaligus bertindak selaku Koordinator Pro-Pasar Sentral Makassar dalam meng-upgrade fasilitas Pasar Sentral Makassar.

Aktivitas jual beli kemudian lebih tertata, karena tempat berdagang yang sebelumnya masih gubuk dibangun menjadi bangunan permanen. Akibat pelaksanaan kebijakan tersebut, para penjual liar kemudian beralih menjadi penjual resmi. Mereka mendapatkan tempat belanja yang bersih, dan bebas lumpur. Untuk menunjang pembangunan mental penduduk seperti yang dicanangkan pemerintah kota, maka pasar ini juga dilengkapi dengan mushalla. Pada akhir 1970, Pasar Sentral dibuka hingga malam hari (Tegas, 11 Agustus 1969:1; Pedoman Rakjat, 2 November 1970).

Dalam hal kebersihan dan keindahan kota, pemerintah mewajibkan seluruh komponen dan masyarakat baik perorangan, rumah tangga, hotel, restoran, asrama, perkantoran, institusi pemerintah maupun swasta memiliki tempat sampah. Bentuknya telah ditentukan oleh Dinas Kebersihan Kota. Sejalan dengan hal tersebut, pemerintah kota juga menggunakan sirene sebagai tanda bagi penduduk untuk membersihkan jalan, selokan, dan pekarangan rumah masing-masing. Kegiatan itu tidak hanya dilakukan oleh penduduk yang tengah berada di rumah, tetapi para pengendara kendaraan wajib berhenti dan ikut membantu kegiatan kebersihan. Sementara para tukang becak dan sopir angkutan disyaratkan 
untuk selalu membawa sapu di kendaraannya. Realitas tersebut membuat Makassar dikenal sebagai kota yang bersih (Pedoman Rakjat, 26 Oktober 1973:1).

Upaya lain yang dilakukan adalah pengembangan kesejahteraan penduduk di tingkat bawah yang dilakukan melalui program Pembangunan Masyarakat Desa (PMD). Selain kegiatan fisik, program ini bertujuan untuk melakukan penyelidikan potensi daerah dan masyarakatnya, serta peningkatan produktivitas dan pengetahuan masyarakat dalam mewujudkan kemajuan. Patompo juga mendirikan lembaga perkreditan, mengintensifkan gotong royong, serta mengefektifkan struktur pemerintahan desa, hingga ke tingkat paling rendah yaitu ORT/ORK ( $A K U P$, Vol. I, Reg. No. 601).

Pemerintah kota juga memerhatikan aktivitas di kalangan pemuda dan remaja. Kegiatan mereka disalurkan melalui klub remaja. Hingga tahun 1973 terdaftar 228 klub. Sejalan dengan kebijakan pemerintah kota, dalam penanganan masalah pemuda, Kepolisian Kota Makassar ikut mendukung program pemerintah kota dengan cara memfasiltasi kegiatan mereka.

Pihak kepolisian Kota Makassar membentuk klub-klub sepeda motor dan sering kali melakukan kegiatan bersama antara lain konvoi keliling kota atau berkumpul di tempat atau acara tertentu. Perlombaan musik seperti festival band se-Kota Makassar juga beberapa kali digelar. Untuk mewujudkan ketertiban masyarakat secara luas, peranan Pagar Pradja cukup besar. Organisasi semacam pamswakarsa itu berhasil melakukan penertiban tempat minum tuak, praktik tuna susila, penertiban di pasar, dan perjudian (AKUP, Vol. I, Reg. No. 594; Pedoman Rakjat, 13 Oktober 1965; 11 Agustus 1973:3; 2 Januari 1974:1). Aturan itu juga diberlakukan kepada anak-anak di bawah usia 17 tahun untuk tidak berkeliaran sesudah pukul 23.00 di tempat umum. Bersama pihak kepolisian, pemerintah kota juga menyusun larangan membuat hingar-bingar, kericuhan, berpakaian tidak senonoh, membuat tulisan atau lukisan yang tidak pantas, dan bergerombol ( $A K U P$, Vol.I, Reg.No.705). Sementara itu, hal-hal yang dianggap bertentangan dengan budaya lokal dan agama dilarang dengan tegas, misalnya melarang pertunjukan dengan gaya dan lagu The Beatles, atau kebijakan 'mengganyang' rok ketat dan rambut sasak ( $A K U P$, Vol.I, Reg. No.867, 2046).

Berbagai macam bentuk pendisiplinan itu merupakan bagian dari upaya mewujudkan masyarakat modern yang teratur. Usaha tersebut disertai dengan kegiatan dan penyediaan fasilitas yang mendukungnya. Selain diselenggarakan berbagai kegiatan dengan nuansa terkini (modern), ruang-ruang kota juga menyediakan prasarana terbaru bertaraf internasional. Pada awal 1970-an, misalnya diperkenalkan hotel yang memenuhi persyaratan internasional. Salah satu hotel tersebut dibangun di bekas Passanggrahan Ujung Pandang dan merupakan milik pemerintah Propinsi Sulawesi Selatan. Pembangunan hotel tersebut sebagai dampak dari skema Penanaman Modal Dalam Negeri (PMDN) dan penetapan Makassar sebagai tujuan wisata. Hotel tersebut dibangun oleh PT. Ujung Pandang International Beach Hotel (Pedoman Rakjat, 10 Januari 1973: 1). ${ }^{1}$

Beragam sarana dan prasarana untuk mendukung kebutuhan pariwisata, antara lain beberapa nightclub bertaraf internasional, pusat keramaian dan hiburan seperti Capitol Cafe, Wisma Ria, Hilman, Marannu, Losari Blue Beach Restaurant \& Bar, dan Sea View Club, yang kesemuanya menampilkan penari internasional dan kelompok band dari Jawa. Acara "Hawaian night" dimeriahkan dengan penari terkenal, seperti Ross Sumantri dan para penari perut.

Perayaan menyambut tahun baru Masehi dilaksanakan semalam suntuk dan didukung oleh pemerintah kota, seperti yang diselenggarakan ketika pergantian tahun 1973 ke 1974 (Pedoman Rakjat, 3 April 1971:1; 29 Oktober 1971:2; 3 Januari 1972:1; 31 Desember 1973:1). Untuk sarana transportasi, tersedia taksi Morante Jaya. Gedung-gedung bioskop dibangun dengan desain modern berpendingin ruangan, seperti Rusa Theater, Bioskop Ratu, dan Bioskop Ujungpandang. Sementara itu, tempat makan bertaraf internasional juga didirikan, seperti Restoran Bambooden yang dibangun sejak awal 1970-an (Pedoman Rakjat, 17 Mei 1973: 2; 2 November 1973:1).

Berbelanja dengan suasana baru ditawarkan saat supermarket modern dibangun tahun 1971 oleh PT. Pantja Daya pimpinan Hasanuddin 
Nawing dan Umar Koan. Bangunan tersebut dilengkapi dengan trotoar yang luas, taman, dan tempat rekreasi. Bangunan berlantai tiga itu berlokasi di Jalan Irian, menempati lahan lebih dari satu hektare. Bangunan di lantai 1 dan 2 direncanakan untuk toko, restoran, salon, tempat rekreasi. Sementara itu, lantai tiga untuk tempat bermain anak. Proyek ini merupakan proyek yang pertama di luar Jawa dengan taraf internasional, dilengkapi dengan alat pendingin, 200 petak toko, dan pelayan berpakaian seragam. Seiring dengan perluasan kota dan untuk mendukung pariwisata, maka pada 1971 diresmikan pula Somba Opu Shooping Centre. Pada 1972, PT. Rekreasi International Makassar membangun lagi shooping centre di Jalan Irian (Pedoman Rakjat, 13 Januari 1972:1; 26 Agustus 1971).

Salah satu tempat terbaik untuk berekreasi adalah Taman Bahari yang berada dalam kompleks Tirta Samudera, di depan Benteng Rotterdam. Tempat rekreasi tersebut dibangun tahun 1968 atas inisiatif para veteran yang dikoordinasi oleh Mursalim Madjid dan Bahang. Desain Bangunan menjorok ke laut ke arah Pulau Lae-Lae. Bangunan itu terdiri atas bar, restoran, toko suvenir, toko kecantikan, panggung terbuka, dan kolam renang. Di tempat itu, juga tersedia tempat untuk penyelenggaraan pertunjukan seni dan budaya, konser musik, fashion show, hingga pertandingan bridge (Majalah Karya, Tahun 1967/1968:6-8; Pedoman Rakjat, 22 Mei 1967; 16 Nov. 1967:1).

Mengenai hal ini, walikota mengatakan bahwa tempat tersebut, ikut memperindah wajah kota, sekaligus menjadi wadah pertumbuhan kesenian daerah. Namun harapan walikota tidak sesuai dengan realitas yang ada, para pelaku pertunjukan seni dan budaya yang diselenggarakan pada berbagai acara di Kota Makassar, justru banyak dilakukan oleh seniman dan budayawan baik dari Jakarta maupun dari luar negeri (Wawancara A. Rachman: Makassar, 13 Oktober 2015).

Ketersediaan sarana hiburan, rekreasi, pariwisata, dan olahraga, bermunculan atas usaha pemerintah serta pihak swasta. Pulau Kayangan yang terletak di depan Kota Makassar adalah salah satu tempat rekreasi favorit warga kota. Pulau Kayangan, selain memiliki panorama laut yang indah, di tempat tersebut, setiap malam minggu diadakan pertunjukan musik, seni budaya, permainan ketangkasan, serta pasar malam. Salah satu kegiatan rutin yang menarik minat pengunjung adalah pemilihan "Ratu Pantai Kayangan”. Di samping Pulau Kayangan, sejak 1970-an, Tanjung Bunga dan Pulau Samalona juga mulai ramai dikunjungi para wisatawan (Pedoman Rakjat, 26 Maret 1968; 23 April 1968; 2,14 Juli 1973:1).

Sarana wisata lain yang dikembangkan sekaligus sebagai wadah pengembangan budaya adalah "Taman Budaja dan Keindahan Alam Udjung Pandang”, atau lebih dikenal sebagai kebun binatang yang terletak di Maccini. Berdasar pada rancangan tahun 1970, sarana wisata ini terdiri atas tujuh objek, yaitu; taman margasatwa, balai budaya, ruang pameran hasil pembangunan, cafetaria, taman bermain anak, ruang perkumpulan kaum ibu, serta akuarium ikan laut dan karang (Pedoman Rakjat, 6 Februari 1970; 11 Januari 1971).

Selain pembangunan sarana dan prasarana, pemerintah kota juga merancang kegiatan tahunan, seperti pecan hiburan dan pameran pembangunan yang mendapat perhatian besar warga kota. Sebelum 1970, kegiatan semacam ini sudah pernah dilakukan beberapa kali dengan nama Makassar Fair, kemudian Ujung Pandang Fair dan Pekan Raya Ujung Pandang (AKUP, Volume I, Reg.No.1421, 1949; Pedoman Rakjat, 20 Agustus 1973:1).

Tempat rekreasi dan hiburan terbesar dalam kota adalah Taman Hiburan Rakyat (THR) Makassar. Berbeda dari tempat wisata lain yang hanya bisa dinikmati kalangan berduit, tempat ini diperuntukkan bagi segenap lapisan masyarakat. Taman Hiburan Rakyat dibangun tahun 1966 dengan tujuan untuk menyediakan sarana hiburan yang sehat dan murah. Sarana hiburan dianggap mampu menciptakan ketentraman dan kesenangan bagi penduduk kota. Pada 1975, THR yang terletak di Jalan Kerung-Kerung dilengkapi dengan panggung terbuka, taman, gedung kesenian, pertokoan, gedung pameran, dan tempat latihan kesenian. Di tempat terpisah yakni di Taman Santai Ria, disediakan bioskop, kolam renang, permainan berhadiah, permainan di atas air, mini Sulawesi, dan restoran terapung ( $A K U P$, Volume I, Reg.No.1472, 1447). 
Pada bidang olahraga, mobilisasi kegiatan dan pengadaan sarana-prasarana mendapat perhatian khusus. Di setiap kampung atau lingkungan diupayakan memiliki lapangan olahraga. Kegiatankegiatan olahraga dikoordinasi dan diselenggarakan secara rutin. Salah satu olahraga yang digemari dan menarik perhatian banyak penduduk kota adalah pacuan kuda.

Pada awal 1970-an, dibangun gelanggang pacuan kuda bertaraf internasional di bawah pengelolaan Djakarta Racing Management. Selain berkuda, permainan sepak bola merupakan salah satu olahraga yang paling digemari. Tim sepak bola Makassar selalu berprestasi dan dibanggakan penduduknya. Pada 1970-an, berhasil menjuarai piala Presiden Soeharto demikian pula pada 1980an dan 1990-an tim ini menjadi juara piala perserikatan. Kegiatan olahraga bersifat nasional juga diselenggarakan di kota ini, seperti Pekan Olahraga Mahasiswa (POM) (AKUP, Volume I, Reg. No. 405).

Di tengah usaha pembangunan mental masyarakat, menjelang akhir dekade 1960-an, pemerintah menyetujui penyelenggaraan kegiatan judi terselubung seperti lotere totalisator (lotto). ${ }^{2}$ Alasan pemerintah menyelenggarakan "judi terselubung" itu adalah untuk mendapatkan dana tambahan guna keperluan pembangunan, khususnya pendirian sekolah dan sarana kesehatan. Pengadaan dana melalui lotto menimbulkan kontroversi. Mereka yang menentang kebijakan pemerintah tentang kegiatan ini menyebutkan bahwa selain bersifat judi dan haram, kegiatan itu pada akhirnya akan merugikan masyarakat yang terus menyandarkan harapan pada keberuntungan.

Meskipun mendapat tentangan dari berbagai pihak, lotto tetap dilaksanakan bahkan pengamanan kegiatannya ditangani langsung oleh Komando Distrik Militer 1408/Djumpandang (Tegas, 18 Juli 1969:1; AKUP, Volume I, Reg.No.1945, 1951; Pedoman Rakjat, 15 Februari 1968). Di setiap kecamatan bahkan kelurahan tersedia agen penjualan lotto. Di samping lotto, masih ada permainan berhadiah lain yang digemari yaitu permainan jack-pot. Berbeda dengan lotto, jack-pot memakai mesin menggunakan uang nominal tertentu. ${ }^{3}$

\section{WACANA PEMBENTUKAN KOTA BUDAYA}

Pada awal Orde Baru, Kota Makassar telah diwacanakan sebagai kota budaya. Untuk mewujudkan impian itu, pemerintah kota mengusahakan segala cara. Pada akhir masa jabatan Walikota Patompo, Makassar telah berubah sebagai kota yang tertata dengan fasilitas modern. Segala sarana yang dianggap merupakan kebutuhan masyarakat perkotaan telah diusahakan. Fasilitas perkantoran, pasar dan pusat bisnis, sarana pendidikan, kesehatan, sarana sosial, rekreasi, hiburan, dan lain-lain telah dibangun. Berbagai bentuk kegiatan guna mengakomodasi kebutuhan masyarakat kota modern juga diselenggarakan. Pemerintah kota beranggapan bahwa mentalitas masyarakat akan terbangun dengan sendirinya, mengikuti kemajuan-kemajuan pembangunan fisik perkotaan.

Menjelang 1980-an, muncul kekuatan baru yang pada masa selanjutnya menentukan nasib dan masa depan kota. Kekuatan baru tersebut adalah pihak swasta atau pemilik modal. Keberadaannya secara perlahan namun pasti "menguasai" ruangruang kota sesuai dengan tujuan dan kepentingannya. Kehadiran pemilik modal merupakan kabar baik bagi pembangunan kota, namun sejauh mana pemerintah kota mampu menciptakan dan sekaligus mengawal regulasi yang berpihak ke segenap warga kota. Realitas ini menunjukkan bahwa pemerintah kota sering kali tidak berdaya menghadapi kepentingan pihak swasta.

Penguasaan ruang-ruang kota oleh pihak swasta tampak pada kawasan Tanjung Bunga, Tanjung Alam, dan sekitarnya. Kawasan yang pada awalnya yang dalam master plan ditetapkan sebagai pusat rekreasi, seni, dan pariwisata untuk mendukung perwujudan kota budaya, akhirnya tidak mampu dipertahankan sesuai dengan rencana semula. Kawasan ini pada 1973 diserahkan ke pihak swasta, PT. Sulawesi Tourism Development Ltd, untuk membangun tempat rekreasi "Delta Remaja" di Tanjung Bunga dan Tanjung Alam. Pada 1976, pemerintah Kota memberi rekomendasi kepada PT. Mataba Karya yang dipimpin Andi Mattalatta untuk mengusaha- 
kan kawasan ini sebagai pusat rekreasi dan obyek pariwisata (AKUP, Vol.I, Reg.No.1442, 1473).

Pada 1979, pemerintah kota menyusun Rencana Pembangunan Delta Tanjung Bunga, sebagai tempat rekreasi yang dibangun dengan mengambil contoh beberapa aspek dari Taman Impian Ancol, Pantai Kuta Bali, Prapat di Sumatera. Tempat rekreasi tersebut dinamakan “Taman Impian Tanjung Bunga”. Sementara itu, di kawasan yang diproyeksikan menjadi pantai seindah Honolulu dan Waikiki ini akan direncanakan dibangun cottages yang bentuk desainnya adalah model rumah Bugis, Makassar, Toraja, dan Mandar. Di tempat ini dibangun juga lapangan olahraga, restoran, gedung pertemuan, kolam renang, taman hiburan, tenda peristirahatan, tempat olahraga air, tempat mandi dan berjemur. Berbagai rencana tersebut mengalami perubahan seiring semakin kuatnya desakan kepentingan pihak swasta, khususnya setelah Lippo Group pada 1995 menandatangani kontrak untuk membangun Lippo Country di atas areal 1000 ha di Tanjung Bunga ("Rencana Pembangunan Delta Tanjung Bunga”. Kotamadya Ujung Pandang, 1979; AKUP, Volume I, Reg.No.1432).

Kehidupan masyarakat perkotaan sejak awal Orde Baru, juga dipengaruhi oleh penyebarluasan teknologi secara masif. Tayangan televisi semakin luas setelah beroperasinya TVRI Makassar pada 1971. Televisi menjadi medium komunikasi massa yang membawa perubahan besar dalam berbagai aspek. Sejalan dengan hal itu, perusahaan nasional yang dipimpin Mohammad Gobel menyediakan 15 ribu pesawat televisi dengan harga murah. Kemudahan komunikasi di Kota Makassar ditunjang pula oleh pembukaan kantor pos di setiap kecamatan dan pemasangan telepon otomat yang mencapai ribuan sambungan (Pedoman Rakjat, 28 Maret 1968; 3 Maret 1969; 12 Desember 1970; 28 Januari 1974:3).

Dalam konteks aktivitas organisasi atau perkumpulan, kehadirannya tidak lagi sebagai bentuk kegelisahan atas persoalan kemasyarakatan. Sebagian berkembang karena dikoordinasi atau dibentuk berdasar pada kepentingan pihak tertentu, terutama pemerintah. Kondisi dan motivasinya berbeda dibanding perkumpulan yang terbentuk pada masa kolonial dan tahun 1950-an.
Meskipun salah satu tujuan utama yang pernah dicanangkan pemerintah kota yaitu menjadi kota budaya, namun baik konsep maupun realitasnya sulit ditemukan dalam ruang-ruang kota. Aktivitas seni dan budaya umumnya dikoordinasi oleh Dewan Kesenian Makassar (DKM), yang dipimpin Rahman Arge. Ia mengatakan bahwa melalui DKM, para pekerja budaya berusaha membina serta meningkatkan mutu dan apresiasi kesenian dalam menjadikan kota ini sebagai kota budaya (Pedoman Rakjat, 26 April 1971; Wawancara F. Syarif: Makassar, 2 Oktober 2015).

Untuk mendukung gagasan tersebut, pada tahun 1967 dibangun Gedung Kesenian di Jalan Irian. Walikota mengatakan upaya tersebut menjadi landasan pembinaan seni budaya di Kota Makassar (Pedoman Rakjat, 3 Juni 1967; 23 Juli 1970). ${ }^{4}$ Akan tetapi, konsep 'pembinaan' yang diperankan pemerintah tidak efektif menciptakan ruang kreasi yang leluasa bagi tumbuh dan berkembangnya kehidupan seni budaya seperti pada dekade 1950-an.

Setelah dekade 1980-an, mentalitas manusia dan masyarakat yang berusaha "didisiplinkan", justru mengalami kemunduran dalam beberapa aspeknya. Makassar yang pernah dibanggakan sebagai kota terbersih di Indonesia, pada awal tahun 1990-an disebut oleh Menteri Dalam Negeri sebagai kota "ujung sampah". Untuk memperbaiki citra tersebut, Walikota Malik B. Masry (19941999) melakukan berbagai usaha perbaikan, antara lain pelebaran jalan dan pemasangan ribuan lampu merkury pada jalan utama untuk mengurangi kesan kumuh pada ruang-ruang kota. Pengaturan pegawai dan penduduk kota, dilakukan melalui "tiga tertib", yakni tertib administrasi/organisasi, sistem, dan sumber daya manusia. Masyarakat digerakkan melalui Lembaga Ketahanan Masyarakat Desa (LKMD), termasuk dalam membersihkan lingkungan. Dalam administrasi pemerintahan, digunakan pendekatan kemitraan yaitu walikota harus bersikap sebagai manajer dan berjiwa entrepreneurship. Termasuk kebijakan melobi langsung pengusaha untuk mendatangkan investasi dalam pembangunan kota (Kompas, 3 April 1995). ${ }^{5}$

Capaian pembangunan khususnya pada lingkungan fisik kota, tidak sepenuhnya diikuti perkembangan masyarakat yang maju dan modern. 
Pembangunan infrastruktur dan berbagai macam 'pengaturan', tidak menciptakan transformasi ide, gagasan, dan perilaku masyarakat yang modern. Hal ini menjadi cerminan kegagalan dalam mewujudkan Makassar sebagai kota budaya. Secara luas tidak terjadi dialog secara bebas soal kebaruan, kekinian dan masa depan, khususnya dalam bidang budaya dan seni. Kemunduran ide dan sempitnya ruang kreativitas menyebabkan miskinnya karya-karya seni dan budaya. Hampir tidak ada polemik sosial kebudayaan. Berbagai persoalan diselesaikan dengan penerbitan peraturan, ketetapan, atau larangan pemerintah.

Senjakala kehidupan budaya di Kota Makassar berlangsung hingga awal abad ke-21 dan dalam perkembangan selanjutnya realitas tersebut tergantikan dengan ikon "kota dunia" yang konsepnya juga masih kabur. Masa lalu dan harapan menjadi kota dunia, pusat turisme, dan kota budaya yang digelorakan dalam lagu "Makassar Djaja" hingga akhir abad ke-20 sulit diwujudkan. Menjauh dari semangat dan harapan seperti yang tergambar pada bait lagu yang digubah oleh J. G. D. Fernandez dan ditulis oleh Moh. Salim, berikut ini (AKUP, Vol. I, Reg. No.1467, 2002).

"Makassar kota indah bandar niaga di timur
Sinar surja thaja gemilang kebangkitanmu
Tempat bahari perkasa mengharumkan
samudra

Mari kita buktikan segala karja kita

Rakjatnja berani berdjiwa pantang mundur

Djebol teratak buruk bangun kota baru

Giat bekerdja satu tekat membangun negara

Djadikan Djumpandang kota Madya

Makassar djaja

Di bawah pantjaran sinar asli Pantjasila madju

Kota indah megah perkasa sepandjang masa

Pantjarlah mekarlah kota indah Makassar

djaja

Kan sinarmu kota angin mamiri sebar namamu

Makmur bahagia keseluruh dunia”.

\section{IRONI MODERNITAS}

Manusia dan masyarakat modern dihadapkan pada dilema atas kemajuan itu sendiri. Fenomena ini melahirkan anggapan bahwa bersentuhan dengan aspek modern justru memundurkan nilai kearifan lokal. Dapat dikatakan bahwa pengaruh kebaikan cara modern sebanding dengan pengaruh jahatnya (Pemberita Makassar, 22 September 1930: 3). Sebagai contoh, pada saat restoran maupun nightclub banyak berdiri 1970-an, yang di satu pihak mendorong banyak perempuan bekerja di tempat tersebut, baik sebagai pramusaji hingga pelayan bar (hostess). Namun di pihak lain, profesi ini dianggap tercela karena umumnya bekerja hingga malam hari, menemani tamu mengobrol, hingga dansa bersama (Majalah Swadaja, 17 Agustus 1971: 8-10).

Hal ini menimbulkan kecemasan, seperti yang disampaikan oleh 15 organisasi wanita di Makassar yang memprotes reklame porno pada 1970-an. Tayangan, iklan, gambar, maupun pernyataan mencolok dan cabul yang dimuat media massa, dinilai bertentangan dengan moralitas. Pada saat bersamaan, di lorong-lorong kampung, bahkan anak-anak pun dengan mudah bisa mengakses film-film dewasa yang banyak disewakan saat teknologi video kaset menyebar (Wawancara Puang Mare, Makassar: 27 Agustus 2016). Kekhawatiran terbesar lainnya khususnya di kalangan orang tua adalah meluasnya bentuk kenakalan remaja. Sebuah permasalahan sosial yang lahir karena perkembangan dan kemajuan kota (Pedoman Rakjat, 20 Januari 1970).

Berbagai macam bentuk konsekuensi dan "kegundahan" yang dirasakan manusia pada masyarakat modern, disikapi dan dinilai secara berbeda oleh setiap pemimpin dan rezim yang berkuasa (Pedoman Rakjat, 27 Maret 1956). Walikota Patompo yang menjabat pada dekade 1960-an, hingga 1978 menyebutnya sebagai "risiko", seperti yang diungkapkan dalam pidatonya pada 8 Mei 1965;

"Setiap kemajuan pastilah mendatangkan persoalan dan kesulitan. Penjebolan terhadap gubuk untuk diganti dengan bangunan yang permanen adalah suatu kemajuan tetapi sekaligus menimbulkan persoalan dan kesulitan. Penggantian alat yang tua dengan yang baru adalah suatu kemajuan tetapi serentak dengan itu membawa pula kesulitan. Pekerjaan pelebaran jalan adalah suatu kemajuan namun membawa pula kesukaran. Makin 
banyaknya anak-anak yang akan bersekolah adalah suatu kemajuan tapi juga mendatangkan kesulitan. Apakah kita akan menyerah kalah atau melarikan diri karena takut menghadapi kesulitan. Dengan tegas kami katakan - tidak" (AKUP, Vol. I, Reg. No. 425).

Walikota Abustam yang memerintah hingga awal dekade 1980-an, menyebut kondisi tersebut sebagai "tantangan” pembangunan. Kemunculan permasalahan disebabkan oleh tantangan pembangunan yang belum bisa diselesaikan. Terlepas dari berbagai pendekatan pembangunan dari setiap rezim yang berganti, dalam kenyataannya, menjelang dekade 1980-an dan setelahnya, permasalahan perkotaan justru semakin kompleks dan sulit diatasi. Permasalahan tersebut meliputi hampir seluruh aspek kehidupan, seperti soal perumahan, lapangan kerja, kemiskinan, sampah, air bersih, birokrasi yang rumit, kriminalitas, semrawut, kumuh, padat, dan lain-lain (Selayang Pandang Kotamadya Ujung Pandang, 1988:9-10).

\section{RUSAKNYA TATA RUANG KOTA}

Kota-kota modern di Indonesia dapat diandaikan sebagai "tempat berpijak yang rapuh", khususnya bagi penduduk berpenghasilan kecil. Realita ini terutama tampak pada ketersediaan sarana perumahan, akses pelayanan publik, dan infrastruktur yang tidak layak. Pemerintah Kota Makassar pada awal Orde Baru juga menghadapi kondisi pemukiman padat, ruang kota yang kumuh, dan meluasnya pemukiman liar. Menghadapi persoalan yang kompleks itu, maka pada awal Orde Baru, pemerintah kota berencana menutup Kota Makassar bagi pendatang baru yang akan menetap dengan membangun rumah (Pedoman Rakjat, 8 Juli 1967).

Momentum terbaik untuk melakukan penataan ulang wilayah kota dan pemukiman yang dapat menjadi dasar pertumbuhan kota, puluhan hingga ratusan tahun ke depan terjadi saat perluasan kota pada 1971. Akan tetapi, kesempatan itu tidak mampu dimanfaatkan secara maksimal, sehingga hanya dalam waktu satu dekade saja, yakni pada 1980-an, kota ini kembali menghadapi permasalahan pemukiman yang tidak teratur, dan tidak berdasar pada master plan kota. Pemukiman tumbuh tidak terkontrol dan perumahan modern yang dibangun tidak memprioritaskan aspek lingkungan. Begitupun, jalan lorong yang kondisinya tidak memadai, sempit, dan tidak tertata ( $A K U P$, Vol. I, Reg. No. 2176).

Kekumuhan dan kesemrawutan adalah persoalan yang tidak mudah diselesaikan oleh pemerintah kota. ${ }^{6}$ Komitmen pemerintah kota pada aspek kebersihan mengalami penurunan dari waktu ke waktu. Pada dekade awal Orde Baru, meskipun pemerintah kota mampu mewujudkan kebersihan lingkungan, namun kesadaran masyarakat masih rendah. Hal ini tergambar pada 1970 yang menunjukkan bahwa dari 72.580 rumah tangga, hanya 3003 rumah tangga atau 4\% berlangganan mobil pengangkut sampah. Dalam peraturan pemerintah kota, 50\% rumah tangga di tepi jalan seharusnya berlangganan sampah mobil pengangkut sampah, $50 \%$ sisanya yang berada pada lorong-lorong dan perkampungan umumnya membakar, menanam dan membuang sendiri sampahnya (AKUP, Vol. I, Reg. No. 2097; Pedoman Rakjat, 24 Januari 1963:1; 16 Agustus 1967).

Prasarana kakus di tiap rumah tangga juga masih rendah, di Lingkungan Bontomarannu, misalnya $70 \%$ penduduknya belum memiliki kakus (Marhaen, 9 September 1960). Begitu pula dengan ketersediaan air bersih yang masih terbatas. Survey yang dilakukan pada akhir 1970-an, tercatat hanya 2,9\% penduduk yang menikmati air ledeng. Sebagian besar lainnya memperoleh air bersih dari kran umum $53,9 \%$, tukang air pikulan $8,3 \%$, dan sumur pribadi $34,2 \%$ ( $A K U P$, Vol. I, Reg. No.1552).

Sebagai masyarakat modern, mentalitas yang mengedepankan partisipasi dan tanggung jawab tidak terbangun secara berkelanjutan. Sebagai contoh, Pasar Sentral yang pada awal 1960-an sudah dibangun secara modern dengan sasaran untuk penggunaan puluhan tahun ke depan, justru berkutat secara terus menerus dengan permasalahan. Beberapa kali mengalami renovasi untuk mengikuti tuntutan zaman, namun bau busuk, kotor, becek, dan keamanan yang tidak terjamin adalah kenyataan yang sulit dihilangkan. Sejalan dengan hal itu, ketika stasiun mobil 
dibangun dan dilakukan penataan jalur lalu lintas, sopir maupun pengguna angkutan umum tidak menganggap stasiun tersebut sebagai tempat pemberhentian kendaraan yang resmi. Mereka tetap menggunakan tempat-tempat di luar stasiun sebagai tempat menurunkan dan menaikkan penumpang (Pedoman Rakjat, 20 Oktober 1970; 30 April 1971).

Kerentanan terhadap pemukiman juga ditandai oleh tetap besarnya potensi kebakaran dan banjir. Tiga kebakaran besar antara bulan Juli dan September 1965 mengakibatkan sekitar 2000 orang kehilangan tempat tinggal. Kebakaran pada April 1966 di Lingkungan Udjung Tanah yang membuat 300 kepala keluarga atau 2000 penduduk kehilangan tempat tinggal. Pada 1968, terjadi dua kebakaran besar, yakni di Kampung Pattingalloang yang menghanguskan puluhan rumah, dan kebakaran pada September 1968, tercatat 150 rumah terbakar dan lebih 1000 orang kehilangan rumah ( $A K U P$, Volume I, Reg.No.425, Pedoman Rakjat, 23 April 1966; 10 Agustus 1968; 9 September 1968). Pada Mei dan Juli 1969, terjadi lagi kebakaran di daerah Pisang Selatan dan Lingkungan Lariangbangi. Pada kebakaran ini, sekitar seribu orang kehilangan tempat tinggal. Menghadapi kenyataan ini, pemerintah kota kemudian mengerahkan Kepala Kampung untuk memantau potensi kebakaran dan menjalankan program perbaikan kampung ( $A K U P$, Volume I, Reg.No.1940; Pedoman Rakjat, 9 Mei 1969; Tegas, 22 Juli 1969:1).

Kebakaran pada 1970-an semakin sering terjadi dan belum ada solusi efektif untuk mengatasinya. Tahun 1970 terjadi beberapa kebakaran, seperti di Lingkungan Parang Lajang, Pasar Tjidu, dan Lingkungan Bontoala. Dari Januari hingga Juli 1973, terjadi 32 kali kebakaran yang 12 di antaranya adalah kebakaran besar yang menghanguskan ratusan bangunan dan berdampak pada ribuan orang. Kebakaran pada 1979 yang terjadi di Lingkungan Rappojawa dan Lingkungan Lette adalah salah satu kebakaran terbesar. Pada tahun yang sama, terjadi kebakaran di Lingkungan Pattingalloang dan Panampu yang menghanguskan 593 rumah dan 743 kepala keluarga atau 4010 orang kehilangan tempat tinggal. Kebakaran yang terjadi pada 1980-an dan setelahnya, banyak disebabkan hubungan arus pendek (korsleting) listrik. Selain terjadi di perkampungan dan perumahan, kebakaran juga terjadi di beberapa pabrik dan perusahaan, seperti pada gedung PT. Sinar Utama di Kelurahan Malimongan bulan Mei 1985 (AKUP, Vol.I. Reg. No.878, 1923, 1926; Pedoman Rakjat, 8 Agustus 1973:1).

Penanganan banjir dan modernisasi kampung pada 1960-an dan 1970-an, memberi pengaruh pada berkurangnya genangan air di beberapa tempat. Perbaikan lingkungan termasuk selokan direncanakan pada separuh wilayah kota yang terdiri atas $50 \%$ perkampungan miskin. Namun karena pekerjaan ini bersifat lokal dan tidak terintegrasi dengan wilayah lain, mengakibatkan banjir tetap terjadi. Pada awal 1970-an, banjir terjadi di Kampung Tionghoa dan pada beberapa daerah yang baru menjadi wilayah kota seperti di Balang Boddong dan Jongaya. Banjir terjadi pula di bagian selatan kota seperti di Gunungsari dan Pabaeng-baeng akibat bobolnya tanggul Sungai Jeneberang di Pandang-pandang. Adapun keberadaan Tanggul Patompo berhasil mengatasi banjir besar yang tiap tahun terjadi di daerah Mariso dan sekitarnya (Tegas, 4 Agustus 1969:1; Pedoman Rakjat, 12 Mei 1970; 2 April 1971:1; 30, 31 Desember 1971; 4,5 Januari 1972:1,2; 24 Maret 1973:1).

Menjelang akhir 1970-an, terjadi beberapa banjir yang dampaknya cukup besar, yakni banjir di Lingkungan Maradekaya yang berdampak terhadap 2.264 penduduk, banjir di Mariso menyebabkan 155 rumah tergenang air serta 560 orang diungsikan, dan banjir di Mamajang membuat 1.125 rumah tergenang dan rusak. Sejak 1980-an, banjir juga mulai menggenangi kompleks perumahan, seperti pada 1984 di Perumnas Panakkukang (AKUP, Vol. I, Reg. No. 1926).

"Setelah tahun 1980-an, selain selokan yang tidak lancar, kapasitas kanal utama yang merupakan muara selokan semakin terbatas. Sejak kemerdekaan tidak pernah lagi ada pembangunan kanal utama, yang juga berfungsi sebagai pencegah banjir. Pembangunan perumahan yang menjamur tidak dibarengi dengan tersedianya selokan yang terintegrasi hingga ke saluran induk (kanal) untuk selanjutnya ke pembuangan akhir. Hal itu yang menyebabkan di sebagian 
besar perumahan, air tetap tergenang dan banjir jika musim hujan" ( $A K U P$, Vol. I, Reg. No. 688).

Ketidaktersediaan saluran air yang terintegrasi dan lancar menjadi salah satu penyebab utama terjadinya banjir. Kebutuhan atas hal tersebut selalu dikalahkan oleh kepentingan pendirian gedung ataupun perumahan, terutama sejak 1980 an, ketika perumahan tumbuh cepat, seperti Perumnas, perumahan BTN, maupun perumahan pengembang swasta. Setiap kompleks perumahan dilengkapi dengan saluran air, namun hampir semua perumahan tidak memiliki saluran pembuangan keluar. Saat gedung dan perumahan belum padat, air masih mampu ditampung oleh lahan kosong di sekitarnya, seperti sawah maupun rawa-rawa. Namun saat semua lahan terpakai, air tidak memiliki saluran pembuangan, sehingga akhirnya menggenangi daerah terendah. Hal ini terlihat saat Perumnas kebanjiran karena resapan air di dekatnya hilang akibat pendirian BTN Agraria yang areanya lebih tinggi ( $A K U P$, Volume I, Reg.No.1928).

Untuk menghindari genangan air dalam rumah, penduduk berinisiatif dengan cara meninggikan lantai rumahnya. Pada era pascaproklamasi hingga memasuki abad ke-21, pemerintah kota abai untuk membangun banjir kanal mengikuti bentuk dan luas kota. Satusatunya banjir kanal yang dibangun dalam program Kampong Improvement Project (KIP) adalah Saluran Pannampu. Pembangunannya dilakukan pada akhir 1970-an. Makassar tidak dirancang dan dipersiapkan untuk menjadi kota modern yang bebas banjir untuk masa depannya.

Persoalan lingkungan, baik kebakaran, banjir, maupun beragam persoalan fisik kota lainnya terjadi bukan saja karena kegagalan penataan ruang. Realita itu karena tidak terjadi transformasi dalam penyusunan peraturan yang merespons perubahan zaman dan perkembangan kota. Peraturan penanggulangan bencana, yang meliputi kebakaran, banjir, gempa bumi, dan persengketaan tanah pada masa Orde Baru masih tetap memakai peraturan yang dibuat pada zaman Belanda. Hingga akhir 1970-an, pemerintah kota belum memiliki Peraturan Daerah yang secara khusus mengatur penanggulangan dan pencegahan kebakaran maupun banjir secara sistematis serta efektif (AKUP, Vol. I,Reg.No.2104). Perkembangan kota menuju metropolitan dengan tata kota yang semakin kompleks dan bangunan serba modern, tidak disertai oleh kemampuan sumber daya manusia yang terampil maupun peralatan yang cukup.

\section{MELUASNYA "PENYAKIT MASYARAKAT"}

Selain persoalan lingkungan fisik dan penataan perkotaan, Kota Makassar menghadapi masalah sosial, seperti tingkat kesehatan yang rendah, pelacuran, dan berbagai bentuk kriminalitas. Jumlah pendertita penyakit kusta justru meningkat pada awal Orde Baru, yang disebabkan perpindahan penderita dari berbagai kabupaten di Sulawesi Selatan sejak Walikota Aroeppala dan selanjutnya Walikota Patompo membangun tempat penampungan di Tamalanrea. Namun karena jumlah penderita kusta yang datang melebihi kapasitas penampungan, maka banyak di antaranya yang hidup menggelandang. Pada akhir 1960-an, penderita kusta disebut "menguasai" Kota Makassar, karena terlihat di mana-mana, baik di jalan raya, lorong, pekarangan pertokoan, halaman mesjid, lapangan, hingga sudut-sudut pasar. Tempat penampungan juga mengalami kesulitan karena biaya operasional yang tidak mencukupi. Jalan keluar yang diajukan pemerintah kota, adalah dengan membuka Pusat Pelatihan Penderita Kusta (Leprosy Training Centre) pada awal tahun 1970-an (AKUP, Vol. I, Reg. No. 1794; Pedoman Rakjat, 11 Juni 1968; 21 September 1970).

Rendahnya tingkat kesadaran penduduk akan kebersihan disebut sebagai penyebab menjangkitnya beberapa penyakit. Kebersihan sebagai semboyan modernisasi awal abad ke-20 tidak mengalami transformasi yang memuaskan sampai menjelang berakhirnya abad ini. Pada pihak lain, perhatian akan arti kesehatan, seperti pemeriksaan penyakit dan pengobatan tidak dilakukan dengan baik. Hal tersebut diperparah dengan tidak adanya akses, pembiayaan, dan kemudahan mendapatkan fasilitas kesehatan, khususnya bagi masyarakat tidak mampu (Pemberita Makassar, 30 Maret 1916:1; Pedoman Rakjat, 18 Januari 1973: 1).

Masyarakat modern juga dihadapkan atas meluasnya penyakit kelamin akibat praktik 
prostitusi yang semakin leluasa. Pemerintah kota berpendapat tidak mungkin berhasil menghilangkan aktivitas pelacuran. Salah satu cara untuk mengatasi persoalan yang ditimbulkannya, maka pada 1970-an dirancang lokalisasi, sehingga memudahkan pengawasan dan kontrol keamanan serta kesehatan (Pedoman Rakjat, 6 Maret 1970; 17 Mei 1973:1). Meskipun disebut sebagai penyakit masyarakat dan "diperangi" sepanjang waktu, namun dalam kenyataannya tetap dan terus menjadi kebutuhan kota modern. Buktinya, pada akhir 1980-an ada puluhan germo atau mucikari yang tersebar dan tinggal di semua kecamatan dalam Kota Makassar ( $A K U P$, Vol.I, Reg. No. 1970).

Pada masa Orde Baru, kriminalitas berkembang dari 'kegagalan' modernisasi meningkatkan tingkat kesejahteraan penduduk yang mengakibatkan meluasnya ketimpangan sosial, kemiskinan, dan pengangguran. Di kampung-kampung dan lorong perkotaan sebagai tempat dengan persoalan sosial terbesar, tumbuh subur bermacam praktik kriminalitas (Pedoman Rakjat, 13 Maret 1963:1; 8 Agutsus 1970; 20 Juli 1971; 15 Mei 1973). ${ }^{8}$ Di tempat ini pula suasana kehidupan kota tetap bercampur baur dengan cara hidup di pedesaan. Para lelaki umumnya masih membawa badik (senjata tajam tradisional Sulawesi Selatan), suka berkumpul di lontang (tempat minum ballo), dan minum ballo (minuman keras khas Makassar) (Tanah Air, 6 Agustus 1960: 2; Pedoman Rakjat, 5 Juni 1967; 2 April 1971).9 Salah satu fenomena kriminalitas yang muncul sejak awal Orde Baru adalah bentuk kekerasan yang dilakukan para pemuda, baik yang dilakukan secara perorangan maupun berkelompok. Perilaku ini kemudian dikenal dengan kenakalan remaja atau pemuda (Pedoman Rakjat, 18 April 1970). ${ }^{10}$

Pada akhir 1960-an, di Kota Makassar tercatat 150 buah perkumpulan yang anggotanya suka berkeliaran dan sering menimbulkan aksi kriminal. Tingkat kenakalan remaja semakin tinggi tahun 1970-an, terutama perkelahian, tawuran, balapan liar, hingga penembakan. Penggunaan senjata api, pemakaian kendaraan milik negara, dan kepemilikan barang-barang berharga dari sebagian anggota kelompok pemuda tersebut menggambarkan latar belakang keluarganya. Banyak di antaranya meru- pakan anak atau keluarga dari orang-orang penting di militer maupun pemerintahan. Pemerintah kota dan polisi berusaha mengatasi soal ini dengan melakukan pembatasan untuk berkeliaran, hingga "menyalurkan" kebiasan balapan dengan rencana membangun sirkuit balap di Maccini (Pedoman Rakjat, 13 September 1968).

Perkelahian antarkelompok dan tawuran semakin sering terjadi. Di beberapa kampung, jalan, atau kompleks perumahan dikenal sebagai pusat perkumpulan pemuda yang sering memicu perkelahian. Masing-masing menampilkan kelompoknya sebagai yang paling hebat, berani, bahkan sadis. Dalam tahap tertentu, mirip seperti geng yang memiliki anggota dengan loyalitas kuat. Di kompleks perumahan militer, seperti Asrama Polisi Jalan Mawas, atau Kelompok Cokonuri di Panakkukang terkenal sebagai tempat pemuda yang sering terlibat perkelahian di berbagai tempat (Tanah Air, 6 Agustus 1960:2; 16 Oktober 1960:2; 20 April 1971).

Muncul generasi muda yang sebagian mengekspresikan dirinya dalam berbagai aksi kekerasan, meski tidak bisa dibilang sebagai kriminalitas murni. Para pemuda dan remaja tersebut senang berkonvoi dengan kendaraan bermotor, balapan, dan tawuran. Tidak jarang ada yang menggunakan senjata api, kendaraan, atau barang-barang milik orang tuanya. Pada pihak lain, pembangunan dan modernisasi menciptakan jurang kesenjangan antara yang kaya dan miskin, antara yang memiliki akses kepada elite dan yang tidak. Hal ini tampak pada sebagian besar kampung dalam kota, kondisi infrastrukturnya maupun fasilitas sosialnya tetap terbelakang dan menyedihkan. Kondisi itu menjadi tempat yang subur berkembangnya berbagai bentuk aksi kriminalitas.

\section{SEKTOR INFORMAL DI PERKOTAAN}

Modernisasi adalah sebuah cita-cita dan harapan besar, dengan segala formulasi idealnya. Akan tetapi, dalam kenyataannya sebagian hanya berisi slogan tanpa arti. Husni Djamaluddin, seorang seniman di Kota Makassar pada awal tahun 1970an mengingatkan bahwa modernisasi hanya omong kosong jika agent of modernization terutama aparat pemerintahan cuma berpidato 
tentang modernisasi, tetapi tidak mampu menerjemahkannya ke dalam praktik pembangunan. Pada sisi lain, mentalitas sebagai manusia modern juga tidak terbangun secara luas. Oleh karena itu, manifestasi sikap modern seperti efisiensi, perencanaan, prestasi, orientasi masa kini dan masa depan diabaikan. Slogan "akselerasi modernisasi 25 tahun" di awal Orde Baru sulit diwujudkan karena baik infrastruktur fisik maupun transformasi sosial masyarakat tidak disiapkan (Pedoman Rakjat, 15 Januari 1972:3). Rezim ini lebih tertarik menyukseskan politik ketertiban guna memfasilitasi pemerintahan yang kuat dan memfasilitasi kepentingan kapitalisme (Berger, 1997:324).

Di sisi lain, mentalitas "korup" tumbuh subur di mana-mana dan dalam berbagai tingkatan. Diskriminasi bentuk baru berkembang dengan latar belakang berbeda. Jika pada masa kolonial, penyebab utamanya karena faktor ras atau kebangsaan, maka pada Orde Baru berdasar latar belakang ekonomi, sosial dan politik. Mereka yang memiliki relasi sosial dan politik akan mendapatkan kemudahan dibandingkan jika tidak memilikinya. Tingkat penghargaan manusia modern juga ditentukan oleh kemampuan keuangan seseorang. Kondisi ini yang melahirkan kuatnya praktek KKN (Korupsi, Kolusi, dan Nepotisme) di beberapa paruh akhir abad ke-20 (Robertson-Snape, 1999: 589-602).

Gambaran kondisi tersebut adalah cerita miris atas tersisihnya penduduk kota yang tidak berdaya. Salah satu pihak yang mengalaminya adalah pekerja di sektor informal maupun pedagang kaki lima. Secara umum, sektor informal mencakup semua pekerjaan yang menghasilkan pendapatan di luar upah formal. Konsep ini dikenal secara luas terutama di negara-negara berkembang atau negara dunia ketiga sejak awal 1970-an (Koo and Peter C. Smith, 1983:219; Tanaka, 2010: 295; Sijuwade, 1993: 43). Sektor ini dianggap sebagai anak kandung modernisasi, karena menjadi penopang baik masyarakat maupun kota modern di Indonesia, namun keberadaannya tidak pernah mendapat perhatian yang layak. Kedudukannya paling rentan terpinggirkan, baik karena ketidakmampuan bersaing, atau kebijakan yang tidak memihaknya. Sektor informal cakupannya sangat luas dengan profesi yang sangat beragam.
Pada bagian ini hanya akan diuraikan tentang profesi tukang becak, dan pedagang kaki lima.

Di masa awal pemerintahan Walikota Patompo, perhatian pemerintah kota pada perbaikan hidup pengemudi becak, dilakukan pemberian becak kepada para tukang becak melalui organisasi Persatuan Pengemudi Betjak. Hal ini dimaksudkan untuk meningkatkan taraf hidup tukang becak melalui upaya mendukung kepemilikan becak. Selain itu, seluruh tukang becak dalam Kota Makassar diwajibkan registrasi untuk mendapatkan surat-surat becak. Pendataan tersebut ditujukan pula untuk memperoleh akses pada program pemerintah kota dalam peningkatan kesejahteraan pengemudi becak, seperti fasilitas Poliklinik Pengemudi Becak di Jalan Lembeh. Perbaikan citra dan harkat pengemudi becak dilakukan dengan penyerahan pakaian seragam pengemudi becak, serta penggantian penyebutan becak menjadi 'tiga roda' (Pedoman Rakjat, 28 April 1966:1; 27 April 1967; 11 Juli 1967). Namun pada pihak lain, pembatasan secara ketat dan "penyingkiran" becak juga mulai dilakukan. Visi pembangunan yang mengedepankan keteraturan, melalui usaha mewujudkan kota yang bersih, tertib, terkendali, membuat ruang gerak becak dibatasi terutama pada ruang-ruang utama perkotaan.

Memasuki tahun 1970-an, keberadaan becak menciptakan permasalahan baru akibat jumlahnya yang sangat besar yakni 12.000, dan ribuan lagi yang tidak tercatat. Pertambahan jumlah becak menyebabkan terganggunya ketertiban lalu lintas, baik di jalan raya, stasiun bis, hingga pasar-pasar. Kesemrawutan yang diakibatkannya dianggap bertentangan dengan pelaksanaan modernisasi dan program keindahan kota. Di samping itu, jumlah kecelakaan lalu lintas yang melibatkan becak cukup besar. Pemerintah kemudian mengeluarkan kebijakan untuk mengurangi jumlah becak dan membatasi produksi becak baru. Pembatasan tersebut berdampak langsung bagi hilangnya mata pencaharian bagi banyak penduduk yang menggelutinya (Pedoman Rakjat, 22 Januari 1970; 17 Februari 1970).

Becak telah menjadi angkutan utama penduduk Kota Makassar pada masa Orde Baru. Kehadirannya sangat dibutuhkan dan memudahkan transportasi bagi banyak kalangan. Namun 
pengemudinya terpinggirkan dan terus terdesak dalam gerak modernisasi. Menjadi tukang becak adalah pilihan termudah saat tidak banyak pilihan lain. Meskipun penghasilannya hanya dapat mencukupi kebutuhan makan sehari-hari, profesi ini tetap bertahan. Ada yang menjalaninya dengan terpaksa, namun tidak sedikit yang menganggapnya sebagai jalan hidup (Pedoman Rakjat, 2 Februari 1951).

Berbagai pekerjaan sektor informal di perkotaan tumbuh dan berkembang sepanjang abad ke-20. Salah satu yang paling menonjol adalah pedagang kaki lima. Pada masa kolonial, juga ada pedagang kaki lima, seperti tukang jual pikulan yang menjual segala barang keperluan sehari-hari, dan dikenal juga sebagai tukang kelontong. Pada masa pasca-proklamasi terutama pada masa Orde Baru, hampir tidak ada bagian kota tanpa kehadiran pedagang kecil, pedagang asongan, dan sejenisnya. Mereka berjualan di mana saja asal memungkinkan, mulai dari pinggir jalan raya, sudut-sudut perumahan, dekat tempat hiburan dan rekreasi, emperan pertokoan, pelabuhan, hingga pusat-pusat perbelanjaan. Mereka pada umumnya berjualan kebutuhan rumah tangga secara eceran, makanan, lauk pauk, sayuran, dan rokok. Para pedagang kecil ini banyak yang mendirikan gubuk untuk tempat berjualan, baik di pasar-pasar maupun di dekat stasiun bis (Pedoman Rakjat, 28 Mei 1953:1; Marhaen, 18 Oktober 1955:1).

Pada dekade 1960-an, Pantai Losari tumbuh sebagai pusat keramaian, khususnya di sore hari hingga tengah malam. Saat itu pula, pedagang eceran berkembang pesat di tempat tersebut. Pedagang eceran yang sebelumnya berjualan hanya pada area sekitar 200 meter, berubah hingga satu kilometer panjangnya dan menutup separuh jalan raya. Mereka berjualan beragam makanan, seperti coto, mie, kacang goreng, sate, minuman, barang kelontong, barang tekstil, dan lain-lain (Tanah Air, 31 Oktober 1960:2).

Fenomena yang sama juga terjadi pada 1970an, saat dibangunnya Taman Hiburan Rakjat (THR) di Lingkungan Bara-baraya dan Jalan Kerung-kerung. Kehadirannya mendorong penduduk di sekitarnya untuk berjualan berbagai kebutuhan pengunjung. Pada periode ini, sektor informal khususnya para pedagang kecil lebih terkenal dengan sebutan pedagang kaki lima. Tempat jualannya terutama di sepanjang jalanjalan utama dan pusat perdagangan ( $A K U P$, Vol. I, Reg.No.1971; Pedoman Rakjat, 1 September 1973:1).

Di Kota Makassar, pedagang kaki lima mengambil peran ekonomi non-formal yang signifikan. Kehidupan penduduk perkotaan banyak ditopang dengan kehadiran profesi ini. Namun seperti juga tukang becak, para pedagang kaki lima, selalu berada dalam bayang-bayang ketidakjelasan akan masa depannya. Mereka rentan menjadi pengangguran atau mengalami penggusuran. Padahal sektor ini telah menjadi penyelamat atas terbatasnya lapangan kerja yang tersedia. Sebagai contoh, pada 1960-an saat rencana pembangunan stasiun bis di depan rumah sakit Pattunuang, maka dilakukan pembongkaran puluhan gubuk jualan dan tempat tinggal pedagang kecil. Penggusuran ini menghilangkan mata pencaharian penduduk yang menggantungkan hidupnya pada aktivitas perdagangan kaki lima atau sektor informal lainnya. Ganti kerugian tidak diberikan karena tanah tersebut disebut milik pemerintah kota.

Aktivitas pedagang kaki lima telah menjadi persoalan perkotaan yang rumit diselesaikan oleh pemerintah kota. Pada 1970-an, pemerintah kota melakukan penggusuran terhadap pedagang kaki lima di jalan-jalan utama. Penggusuran antara lain dilakukan di wilayah Kecamatan Mariso, seperti di sepanjang jalan: Bulusaraung, Irian, Diponegoro, K.H. Agus Salim, Timor, Sumba, Lombok, Serui, Sulawesi, Bacan, dan Nusakambangan. Puluhan hingga ratusan pedagang kaki lima terjaring dalam setiap operasi penertiban yang rutin dijalankan. Sejak 1970-an hingga akhir abad ke-20, dengan dalih ketertiban lalu lintas, kebersihan, dan keindahan kota, pedagang kaki lima seolah dalam persimpangan. Antara berjuang mempertahankan aktivitasnya dan berada dalam bayang-bayang penggusuran (Tanah Air, 7 September 1960:1; Pedoman Rakjat, 1 September 1973: 1; 19 Maret 1974:1).

\section{SIMPULAN}

Ruang-ruang modern di Makassar masa Orde Baru tidak disertai dengan tumbuhnya kesadaran 
masyarakat berdasar logika rasional. Hal itu merupakan tantangan yang mendasari harapan terciptanya (kota) budaya yang memenuhi nilainilai kemajuan. Campur tangan pemerintah yang terlalu jauh terhadap kehidupan warga kota, justru melahirkan bentuk baru hubungan sosial. Terbentuk suatu kepatuhan sosial yang berdampak pada keseragaman perilaku dalam menyikapi perubahan. Hal itu berpengaruh pada kemunduran kehidupan budaya. Citra kosmopolis pada ruang perkotaan tergantikan dengan kota yang semakin bercorak etnis. Kreativitas dan aktivitas kebudayaan tidak berkembang semeriah masa sebelumnya. Wacana pada awal Orde Baru untuk menjadikan Makassar sebagai kota budaya gagal diwujudkan.

Sikap kemodernan ditunjukkan dengan lahirnya masyarakat konsumtif, terutama pada benda atau barang kapitalisme. Kemampuan merespons kemajuan dan kebaruan tidak diimbangi dengan kemampuan mentransformasi nilai-nilai modernitas. Tidak terjadi dialektika antara unsur baru dan lama, atau antara apa yang lokal dan apa yang dari luar. Oleh karena itu, tidak tumbuh tradisi kemodernan yang khas dan berkelanjutan. Sebagai contoh, "kebersihan" yang dikampanyekan sebagai simbol modernitas sepanjang abad ke-20, tidak melahirkan mentalitas yang menganggapnya sebagai salah satu dasar kehidupan modern hingga akhir abad. Perilaku mengabaikan kebersihan dengan mudah ditemukan di pasar modern, perumahan modern, stasiun modern, pelabuhan modern, hingga sekolah modern. Sikap apatis tampak pada ketidakpedulian pada kepentingan bersama.

Anomali modernitas semakin kompleks dan mudah dibaca sebagai ironi modernitas karena kesenjangan antara pemecahan yang ditawarkan ide-ide modern, setara dengan dampak buruk yang ditimbulkannya. Sekelumit kondisi tersebut disebut sebagai "permasalahan sosial", bentuk penghalusan bahasa untuk tidak menyebutnya "kegagalan" proyek modernis setelah dekade 1970-an. Modernisasi yang massif dan besarbesaran, membawa dampak buruk pada lingkungan fisik maupun kehidupan masyarakat. Persoalan lingkungan ditandai dengan ancaman banjir, kebakaran, kesemrawutan, hingga kemacetan. Di samping itu, persoalan pengang- guran, kriminalitas, prostitusi, kemiskinan juga terus bertambah. Masyarakat kelas atas terjangkit budaya koruptif dan masyarakat kelas bawah semakin mengalami ketidakberdayaan. Tragisnya, dampak buruk modernisme, paling dirasakan oleh kelompok sosial dan masyarakat paling rentan, terutama yang tidak memiliki akses pada kekuasaan, penduduk miskin, tidak bersekolah, dan terbelakang. Meskipun demikian, modernisme selalu muncul dengan fantasi-fantasi baru yang kembali mampu membangkitkan harapan membebaskan dan menjadi ilusi yang dibutuhkan.

\section{CATATAN}

${ }^{1}$ Saat ini, di tempat tersebut berdiri Hotel Aryaduta Makassar.

${ }^{2}$ Lotto adalah sebuah permainan pemasangan nomor undian berhadiah.

${ }^{3}$ Agen penjualan lotto, jumlahnya hampir ratusan, tersebar di Kecamatan: Wajo 16 agen, Makassar 17 agen, Udjung Pandang 24 agen, Mariso 10 agen, Udjung Tanah 4 agen, Bontoala 12 agen, Tallo 2 agen, dan Kecamatan Mamadjang 6 agen, serta 3 agen di luar kota. Mesin jack-pot terdapat di 21 lokasi, yakni di Bambooden dan Sam Tjiong di Jalan G.Latimojng, Ban Hien, Fat Heng, Goan Hap, Goan Thong di Jalan Sulawesi, Hong Fong dan Liem Hien di Jalan Timor, Foe Nam di Jalan Nusantara, Italiano dan Sin Lok Nam di Jalan Ranggong, Fo Tjiong dan Lo Yap Tjing di Jalan Bali, Wisata di Jalan Pattimura, Gran Hotel di Jalan Achmad Yani, Taman Bahari di Jalan Ujung Pandang, Eva Ria di Jalan Pasar Ikan, Veda Store dan Passangrahan di Jalan Somba Opu, Khun Hien di Jalan Nusantara, dan di Pulau Kajangan. Lihat AKUP, "Walikotamadya Makassar: Surat 12 Januari 1968 tentang Lotto”. Volume I, Reg.No.1947; "Badan Usaha Lotto Indonesia Cabang Makassar: Surat 30 Mei 1968 tentang Daftar Nama Agen dan Omset Penjualan”. (Makassar: BAPD Sulsel, 2004).

${ }^{4}$ Selain DKM, lembaga seni budaya yang lain, di antaranya; Kesatuan Aksi Seniman Budayawan Indonesia (KASBI) Sulawesi Selatan, yang dipimpin Husni Djamaluddin. Ada pula Akademi Kesenian, yang bertempat di bekas gereja Benteng Rotterdam. 
${ }^{5}$ Beberapa capaian Walikota Malik B. Masry, dalam menarik investasi adalah; pembangunan kota baru di Tanjung Bunga oleh Lippo Grup, dan rencana pendirian Makassar Imperial Resort Hotel. Pengusaha Grup Matahari mendirikan Makassar Mall, dan merancang sebuah plaza. Kelompok Pasar Raya pada 1995 berencana mengelola dua buah pulau yakni Lae-lae dan Samalona. Peningkatan status Bandara Hasanuddin menjadi internasional pada Januari 1995, dan rancangan pembukaan Pelabuhan Samudera Makassar.

${ }^{6}$ Sebagai perbandingan, pada 1950 -an petugas sampah hanya 567 orang, jauh lebih rendah dibanding pada masa kolonial sebanyak 1800 orang dan pada masa NIT 1200 orang.

${ }^{7}$ Peraturan mengenai penanggulangan bencana yang tetap mengacu pada peraturan yang diterbitkan pada masa Kolonial Belanda di antaranya: Peraturan kebakaran tahun 1915, Peraturan kebersihan tahun 1923, Peraturan gangguan tahun 1929.

${ }^{8}$ Kasus kriminalitas seperti pencurian dijalankan secara terorganisasi dan terencana. Sebagai contoh aksi komplotan pencuri ban mobil yang dilakukan dengan berani dan profesional. Pelakunya memasuki pekarangan rumah seseorang dan dengan cepat dapat mengambil ban mobil yang terpasang hanya dalam beberapa menit. Pada 1970-an, kawanan pencuri dapat membongkar tempat-tempat terkunci dan dijaga pihak keamanan. Seperti pencurian besar-besaran di Pasar Sentral pada Agustus 1970. Namun secara umum, tingkat pencurian dapat dikurangi, sejak kepolisian mendapat bantuan dari tentara, melalui Gerakan Tampar Kodim 181/Makassar yang mulai berjalan awal 1970-an.

${ }^{9}$ Pada masa Orde Baru, keberadaan lontang tetap menonjol di beberapa bagian kota. Citra kampung dan lorong di perkotaan tetap lekat dengan kebiasaan minum ballo'dan mabuk.

${ }^{10} \mathrm{Pada}$ awal tahun 1970-an, beberapa pihak termasuk polisi membedakan arti "kejahatan" dan "kenakalan". Kejahatan adalah perbuatan yang dilakukan seseorang dengan penuh kesadaran dan menyadari akibatnya baik yang menimpa dirinya maupun orang lain. Kenakalan adalah perbuatan yang dilakukan tanpa disadari kemungkinan dan akibatnya atau dilakukan hanya untuk menarik perhatian, ikut-ikutan dan ingin mendapat pujian.

\section{UCAPAN TERIMA KASIH}

Artikel ini merupakan bagian dari Disertasi yang ditulis pada Program Doktor Ilmu-ilmu Humaniora (Sejarah), Fakultas Ilmu Budaya Universitas Gadjah Mada. Penulis mengucapkan terima kasih atas nasihat akademik dan kontribusi perspektif dari Prof. Dr. Bambang Purwanto, M.A. dan Dr. Sri Margana, M.Phil.

\section{REFERENSI}

Arsip Kotamadya Ujung Pandang (AKUP) (2004). "Berkas Pengembangan Perkotaan oleh Abustam Selaku Ketua Umum BKS AKSI”. Makassar: BAPD Sulsel, Vol.I, Reg. No. 2176.

AKUP (2004). "Badan Usaha Lotto Indonesia Cabang Makassar: Surat 30 Mei 1968 tentang Daftar Nama Agen dan Omset Penjualan”. Makassar: BAPD Sulsel, Vol. I, Reg. No. 1948.

AKUP(2004). "Camat Ujung Tanah: Surat Tahun 1969 tentang kebakaran”. Makassar: BAPD Sulsel, Vol. I, Reg. No. 1926.

AKUP(2004). “Camat Ujung Tanah: Surat Tahun 1969 tentang Kebakaran”. Makassar: BAPD Sulsel, Vol. I, Reg. No. 1926;

AKUP (2004). "Daftar Mucikari/Germo dan Lokasinya di Kotamadya Ujung Pandang”. Makassar: BAPD Sulsel, Vol. I, Reg. No. 1970.

AKUP (2004). "Dinas Pemadam Kebakaran Tahun 1977 tentang Penanggulangan

Bencana dalam Kotamadya Ujung Pandang”. Makassar: BAPD Sulsel, Vol. I, Reg. No. 2104.

AKUP(2004). "DPRD Kotamadya Makassar: SK 1967 tentang Penetapan Lagu Makassar

Djaja sebagai Lagu Resmi Kotamadya Makassar". Makassar, BAPD Sulsel, Vol.I, Reg. No. 2002.

AKUP(2004). “DPRD Kotamadya Makassar: SK 26 Januari 1968 tentang penyelenggaraan Lotere Totalisator (Lotto)". Volume I, Reg.No.1945. 
AKUP (2004). "DPRD-GR Kotapraja Makassar: Seri Surat-surat Keputusan tahun 19721980. BAPD Sulsel, Vol.I, Reg.No.705.

AKUP (2004). "DPRD-UP: SK 1981-1983 tentang Berkas Kerjasama Kotamadya Ujung Pandang dengan Kota Lismore (Australia)”. Makassar: BAPD Sulsel, Volume I, Reg.No.688.

AKUP (2004). "Kepala Kecamatan Bontoala: Surat tahun 1968-1969 tentang Pelaksanaan Penjualan Lotto dan Permainan Ketangkasan”. Makassar: BAPD Sulsel, Volume I, Reg.No.1949.

AKUP(2004). "Kepala Lingkungan Parang: Surat tahun 1976-1984 tentang Banjir di Lingkungan Parang”. Makassar: BAPD Sulsel, Volume I, Reg.No.1928.

AKUP (2004). "Komandan Komando Distrik Militer 1408: Surat Perintah tanggal 26 Juli 1969 tentang Penunjukan Pengawas Keamanan di Proyek Lotto Makassar", Makassar: BAPD Sulsel, Vol. I, Reg.No.1951.

AKUP (2004). "Laporan Tahun 1969-1982 tentang Kegiatan yang Telah dan Belum Dilaksanakan”. BAPD Sulsel, 2004. Vol.I, Reg.No.594.

AKUP (2004). "Laporan Tahun 1972 tentang Rencana Kerja Pembangunan Masyarakat Desa (PMD). BAPD Sulsel, Volume I, Reg.No.601.

AKUP (2004). "Laporan Tahun 1974-1985 tentang Kebakaran dalam Wilayah Kotamadya Ujung Pandang"; Vol.I.Reg.No.878.

AKUP (2004). "M.Saleh Busthami: Paper 1970 tentang Masalah Kebersihan Kota”. Makassar: BAPD Sulsel, Volume I, Reg.No.2097.

AKUP (2004). 'Mendagri: SK 1965 tentang Penunjukan M.Daeng Patompo sebagai Kepala Daerah Kotapraja Makassar”. Makassar: BAPD Sulsel, Vol. I, Reg.No.425. AKUP (2004). "Mendagri: SK 1965 tentang Penunjukan Patompo sebagai Kepala Daerah”. Makassar: BAPD Sulsel, Vol. I, Reg.No.425.

AKUP (2004). 'Penjelasan Walikotamadya Makassar tentang Pola Pembangunan
Daerah Tahun 1969”. Makassar: BAPD Sulsel, Volume I, Reg.No.1469.

AKUP (2004). "Seri Surat-surat DPRD Kotamadya Ujung Pandang mengenai Taman Hiburan Rakyat Ujung Pandang”, Volume I, Reg.No.1472.

AKUP (2004). "Seri Surat-surat mengenai Masalah Pembangunan dan Pengelolaan Taman Hiburan Rakyat (THR) Kerungkerung 1971-1978”. Makassar: BAPD Sulsel, Volume I, Reg.No.1447.

$A K U P$ (2004). "Seri Surat-surat Mengenai Proyek Bantuan Luar Negeri”. Makassar: BAPD Sulsel, Volume I, Reg.No.1552.

AKUP (2004). "Surat PT. Maskapai Asuransi kepada Walikota tentang Penetapan Lokasi Tanjung Bunga”. Makassar: BAPD Sulsel, Volume I, Reg.No.1432.

AKUP (2004). "Surat-surat Tahun 1967-1969 tentang musibah kebakaran”. Makassar: BAPD Sulsel, Volume I, Reg.No.1940.

AKUP (2004). "Surat-surat Pembangunan Kota Makassar 1967-1981”. Vol. I, Reg.No.1467. AKUP (2004). "Surat-surat tahun 1961-1970 tentang Bencana Kebakaran”. Vol.I, Reg.No.1923.

AKUP(2004). "Walikota Makassar: Surat tanggal 13 Mei 1969 tentang Larangan Pertunjukan dengan Gaya dan Lagu The Beatles". BAPD Sulsel, Volume I, Reg.No.2046.

$A K U P$ (2004). "Walikota Makassar: Surat tanggal 26 Juni 1965 tentang Penggajangan Rok Ketat dan Rambut Sasak". Vol.I, Reg.No.867.

AKUP (2004). "Walikotamadya Makassae: Surat tahun 1970 tentang razia terhadap penderita kusta yang berkeliaran”. Makassar: BAPD Sulsel, Volume I, Reg.No.1971.

AKUP (2004). "Walikotamadya Makassar: Surat 12 Januari 1968 tentang Lotto”. Vol.I, Reg. No. 1947.

AKUP (2004). "Walikotamadya Makassar: Surat

Tahun 1966 tentang Perawatan Penderita Kusta”. Makassar: BAPD Sulsel, Volume I, Reg.No.1794.

AKUP (2004). "Walikotamadya Ujung Pandang: Seri Surat-surat Keputusan tahun 19601986”. Makassar: BAPD Sulsel, Volume I, Reg.No.405. 
AKUP (2004). "Walikotamadya Ujung Pandang: SK tentang Pekan Raya Ujung Pandang tahun 1977". Volume I, Reg.No.1421.

AKUP (2004). "Walikotamadya Ujung Pandang: Surat-surat tahun 1976 mengenai Kawasan Tanjung Bunga”. Volume I, Reg.No.1442.

AKUP (2004). "Walikotamadya UP: Laporan tanggal 11 Des.1972 - 12 Juli 1982 tentang Beberapa Permasalahn Kota”. Makassar: BAPD Sulsel, Volume I, Reg. No. 580.

AKUP (2004). 'Surat-surat Walikota Ujung Pandang tentang Daerah Wisata Tanjung Bunga”. Makassar: BAPD Sulsel, Volume I, Reg.No.1473.

Asba, Abdul Rasyid (2000). Makassar Kota Maritim. Jakarta: Departemen Pendidikan dan Kebudayaan.

Berger, Mark T. (1997). "Old State and New Empire in Indonesia: Debating the Rise and Decline Suharto's New Order." Third World Quarterly, Vol.18, No.2.

Dokumen (1988). "Selayang Pandang Kotamadya Daerah Tingkat II Ujung Pandang Tahun 1988”. Makassar: Dokumen Pemerintah Kota

Foucault, Michael (1995). Discipline and Punish: The Birth of the Prison. New York: Vintage Books.

Jellinek, Lea (1994). Seperti Roda Berputar. Perubahan Sosial Sebuah Kampung di Jakarta. Jakarta: LP3ES.

Jones, Tod (2015). Kebudayaan dan Kekuasaan di Indonesia. Kebijakan Budaya Selama Abad ke-20 hingga Era Reformasi. Jakarta. KITLV-Obor.

Kompas, 3 April 1995.

Koo, Hagen and Peter C. Smith (1983). "Migration, the Urban Informal Sector, and Earnings in the Philippines." The Socioological Quarterly, Vol.24, No.2.

Limbugau, Daud (1989). "Perjalanan Sejarah Kota Maritim Makassar Abad 19-20”, dalam Mukhlis, Persepsi Sejarah Kawasan Pantai Makassar, Makassar: UNHAS-YIIS.

Luhukay, Hanock (tth), Dari Makassar ke Ujung Pandang. Catatan Perobahan Ketatanegaraan, Tata Pemerintahan dan Kehidupan Sosial Sebuah Kota Besar. Manuskrip tidak diterbitkan.
Majalah Karya, Tahun 1967/1968.

Majalah Kotapradja, No.9-10, Tahun VII-1978.

Majalah Swadaja, 17 Agustus 1971.

Marhaen, 18 Oktober 1955.

Marhaen, 9 September 1960.

Mattaliu, Abdurrazaq dan Andhy Pallawa, H.M.

Dg. Patompo. Biografi Perjuangan. Ujung

Pandang: Yayasan Pembangunan Indonesia.

Paeni, Muhlis, dkk. (1985). Sejarah Sosial Daerah Sulawesi Selatan. Mobilitas Sosial Kota Makassar, 1900-1950. Jakarta: Departemen Pendidikan dan Kebudayaan.

Pedoman Rakjat, 11 Agustus 1973.

Pedoman Rakjat, 20 Juli 1971.

Pedoman Rakjat, 8 Agutsus 1970.

Pedoman Rakjat, 1 Mei 1970.

Pedoman Rakjat, 1 September 1973.

Pedoman Rakjat, 1 September 1973.

Pedoman Rakjat, 10 Agustus 1968.

Pedoman Rakjat, 10 Januari 1973.

Pedoman Rakjat, 10 Mei 1966.

Pedoman Rakjat, 11 Agustus 1973.

Pedoman Rakjat, 11 Januari 1971.

Pedoman Rakjat, 11 Juni 1968,

Pedoman Rakjat, 12 Desember 1970.

Pedoman Rakjat, 12 Mei 1970.

Pedoman Rakjat, 13 Januari 1972.

Pedoman Rakjat, 13 Maret 1963.

Pedoman Rakjat, 13 Oktober 1965.

Pedoman Rakjat, 13 September 1968.

Pedoman Rakjat, 15 Februari 1968.

Pedoman Rakjat, 15 Januari 1972.

Pedoman Rakjat, 15 Mei 1973.

Pedoman Rakjat, 16 Agustus 1967.

Pedoman Rakjat, 16 November 1967.

Pedoman Rakjat, 17 Februari 1970.

Pedoman Rakjat, 17 Mei 1973.

Pedoman Rakjat, 17 Mei 1973.

Pedoman Rakjat, 18 April 1970.

Pedoman Rakjat, 18 Januari 1973.

Pedoman Rakjat, 19 Maret 1974.

Pedoman Rakjat, 2 April 1971.

Pedoman Rakjat, 2 April 1971.

Pedoman Rakjat, 2 Februari 1951.

Pedoman Rakjat, 2 Januari 1974.

Pedoman Rakjat, 2 November 1970.

Pedoman Rakjat, 2 November 1973.

Pedoman Rakjat, 2,14 Juli 1973.

Pedoman Rakjat, 20 Agustus 1973. 
Pedoman Rakjat, 20 Januari 1970.

Pedoman Rakjat, 20 Oktober 1970.

Pedoman Rakjat, 21 Juni 1963.

Pedoman Rakjat, 21 September 1970.

Pedoman Rakjat, 22 Januari 1970.

Pedoman Rakjat, 22 Mei 1967.

Pedoman Rakjat, 23 April 1966.

Pedoman Rakjat, 23 April 1968.

Pedoman Rakjat, 23 Juli 1970.

Pedoman Rakjat, 24 Januari 1963.

Pedoman Rakjat, 24 Maret 1973.

Pedoman Rakjat, 25 Februari 1967.

Pedoman Rakjat, 26 Agustus 1971.

Pedoman Rakjat, 26 April 1971.

Pedoman Rakjat, 26 Januari 1968.

Pedoman Rakjat, 26 Maret 1968.

Pedoman Rakjat, 26 Oktober 1973.

Pedoman Rakjat, 27 April 1967; 11 Juli 1967.

Pedoman Rakjat, 27 Maret 1956.

Pedoman Rakjat, 28 April 1966.

Pedoman Rakjat, 28 Januari 1974.

Pedoman Rakjat, 28 Maret 1968.

Pedoman Rakjat, 28 Mei 1953.

Pedoman Rakjat, 28 Oktober 1967.

Pedoman Rakjat, 29 Oktober 1971.

Pedoman Rakjat, 3 April 1971.

Pedoman Rakjat, 3 Januari 1972.

Pedoman Rakjat, 3 Januari 1972.

Pedoman Rakjat, 3 Juni 1967.

Pedoman Rakjat, 3 Maret 1967.

Pedoman Rakjat, 3 Maret 1969.

Pedoman Rakjat, 30 April 1971.

Pedoman Rakjat, 30, 31 Desember 1971.

Pedoman Rakjat, 31 Desember 1973.

Pedoman Rakjat, 4, 5 Januari 1972.

Pedoman Rakjat, 5 Juni 1967.

Pedoman Rakjat, 5 Mei 1966.

Pedoman Rakjat, 5 September 1968.

Pedoman Rakjat, 6 Februari 1970.

Pedoman Rakjat, 6 Maret 1970.

Pedoman Rakjat, 8 Agustus 1973.

Pedoman Rakjat, 8 Juli 1967.

Pedoman Rakjat, 9 Februari 1967.

Pedoman Rakjat, 9 Mei 1966.

Pedoman Rakjat, 9 Mei 1969.

Pedoman Rakjat, 9 September 1968.

Pemberita Makassar, 22 September 1930.

Pemberita Makassar, 30 Maret 1916.
Poelinggomang, Edward L. (2002). Makassar Abad XIX. Studi tentang Kebijakan Perdagangan Maritim. Jakarta: KPG.

Pradadimara, Dias (2005). "Penduduk Kota, Warga Kota, dan Sejarah Kota: Kisah Makassar”. Dalam Freek Colombijn, dkk., Kota Lama Kota Baru. Sejarah Kota-Kota di Indonesia. Yogyakarta: Penerbit Ombak.

Robertson-Snape, Fiona (1999). "Corruption, Collusion, and Nepotism in Indonesia", Third World Quarterly. Vol.20, No.3, (Jun).

Sekimoto, Teruo (2005). "Pakaian Seragam dan Pagar Beton: Mendandani Desa pada Masa Orde Baru Tahun 1970-an dan 1980-an”, dalam Henk Schulte Nordholt. Outward Apperances: Trend, Identitas, Kepentingan. Yogyakarta: LKiS - KITLV.

Sijuwade, Philip O (1993). "Migration, the Urban Informal Sector, and Earning in Nigeria". International Review of Modern Sociology. Vol. 23, No.2.

Studies in Urban Development and Planning. Holland: Foris Publications.

Sukatanya, Yudhistira dan Goenawan Monoharto (2000) Makassar Doeloe Makassar Kini Makassar Nanti. Makassar: Yayasan Losari.

Sutherland, Heather (1986). "Ethnicity, Wealth, and Power in Colonial Makassar: A Historiographical Reconsideration”, dalam Peter J.M. Nas (ed.), The Indonesian City.

Sutherland, Heather (2011). "Whose Makassar? Claiming Space in a Segmented City", Comparative Studies in Society and History, $53(4)$.

Tanaka, Victor (2010). “The Informal Sector' and the Political Economy of Development". Public Choice, Vol.145, No.1/2 (October).

Tanah Air, 16 Oktober 1960.

Tanah Air, 31 Oktober 1960.

Tanah Air, 6 Agustus 1960.

Tanah Air, 7 September 1960.

Tanah Air, 20 April 1971.

Tegas, 11 Agustus 1969.

Tegas, 18 Juli 1969.

Tegas, 22 Juli 1969.

Tegas, 4 Agustus 1969. 


\section{DAFTAR INFORMAN}

Puang Mare, 27 Agustus 2016.

F. Syarif, 2 Oktober 2016.

A. Rachman, 13 Oktober 2016. 